doi: 10.17492/manthan.v2i2.8609

\title{
Institutional Factors and Job Satisfaction of College Teachers: A Study for West Bengal
}

\author{
Suhas Roy* and Swapan Kumar Roy**
}

\begin{abstract}
Job satisfaction of college teachers has paramount importance in the development of a country. These teachers supply the nation her workforce. The objective of the present paper is to find out whether institutional factors like pay, promotion, reputation of the institution, research or up gradation facilities, infrastructure of the college, medium of instruction, work environment and the like are responsible for differences of satisfaction levels as enjoyed by the college teachers. Teachers serving in the degree level colleges affiliated by different universities of West Bengal have been taken as samples for filling up a questionnaire containing 55 statements designed to constitute a 5-point Likert scale. The present paper found that pay and allowances, promotion, superannuation, college specific criteria, students related matter, examination-admission-election processes, infrastructure facilities, supervision, co-workers and stakeholders, work environment and community support have influences on job satisfaction of college teachers.
\end{abstract}

Keywords: Job satisfaction, Institutional factors, Pay, Promotion, Supervision, Work environment, Community support.

\subsection{Introduction}

Job satisfaction refers to what an employee simply feels about his job. Spector defines it as what people feel about different aspects of their jobs (Spector, 1997). Job satisfaction of college teachers has paramount importance in the development of a country. These teachers supply the nation her workforce. The quality of workers is a function of job satisfaction of the teaching community.

*Associate Professor, Department of Commerce, Bethuadahari College, West Bengal. ** Assistant Professor, Department of Commerce, Bethuadahari College, West Bengal. 


\subsection{Review of Literature}

Feldman and Arnold (1983) defined job satisfaction as the amount of overall positive affect that individuals have towards their jobs (Feldman \& Arnold, 1983). It is a set of favourable or unfavourable feelings with which employees view their work $(\mathrm{K} \&$ Newstorm, 1989). Hulin and Judge (2003) advocated that job satisfaction includes multidimensional psychological responses to one's job, and such responses have cognitive, affective and behavioural components (Hulin \& Judge, 2003). Job satisfaction is a predictor of teacher retention, a determinant of teacher commitment, and a contributor to teacher effectiveness (Shann, 1998). Roy and Roy (2013) found that job satisfaction of college teachers is significantly different in accordance with their demographic or personal characteristics like age, gender, educational qualifications, marital status, experience, designation etc. (Roy \& Roy, 2013).

Job satisfaction of college teachers is also likely to be dependent on institutional factors like, pay, promotion, reputation of the institution, research or up gradation facilities, infrastructure of the college, location of the college, quality of the students, superannuation benefits, dearness allowances, revision of pay and allowances, pupilteacher ratio, supervision, relationship with co-workers, relationship with non-teaching staff, working hour, workload, reporting time, discrimination in responsibility, attitude of the governing body, freedom at class, medium of instruction and work environment (Roy, 2015).

The objective of the present paper is to find out whether institutional factors as mentioned above are responsible for differences of satisfaction levels as enjoyed by the college teachers.

\subsection{Research Methodology}

Teachers serving in the degree level colleges affiliated to different universities of West Bengal have been contacted for filling up a questionnaire. The questionnaire contained 55 statements and the teachers were asked to put a tick mark against each statement in appropriate box out of five boxes following Likert's 5- point scale earmarked as: not at all satisfied, not satisfied, somewhat satisfied, satisfied and highly satisfied. These 55 statements are actually 55 factors on which job satisfaction of a college teacher is dependent. Job satisfaction is supposed to be largely dependent on pay and allowances. More specifically, there are nine aspects of pay and allowances that have been considered to represent pay and allowances of a college teacher. These separate aspects are technically called as facets. Once the responses to the questions are 
obtained, we construct a frequency distribution against each option by studying the responses. If the frequency obtained for any particular option is not significantly different from other options, then we cannot say that most of the college teachers are either satisfied or not satisfied with their pay and pay scale. Here lies the importance of using chi-square statistic. The null hypothesis is that there exists no significant difference amongst the five options. When the chi-square statistic is found to be more than the table value of the same statistic with $(5-1=4)$ degrees of freedom then the null hypothesis is rejected and the alternative hypothesis is accepted. At 5\% level of significance, the chisquare statistic should be more than 9.49 with 4 degrees of freedom, for us to reject the null hypothesis. In the findings section, the values of chi-square statistic have been earmarked with asterisks when we observe a significant difference. The various components of job satisfaction have the following aspects: 'promotion' has 4 aspects, 'superannuation' has 3 aspects, 'college specific criteria' has 8 aspects, 'students related factors' has 4 aspects, 'examination, election, administration related factors' has 3 aspects, 'infrastructural facilities' has 10 aspects, 'supervision' has 6 aspects, 'coworkers' has 5 aspects and 'work environment' has 2 aspects. The rest of the questions are related with overall satisfaction of the teacher for his job of teaching in a college.

The universities that affiliated the colleges under study were Calcutta University, West Bengal State University, University of Burdwan, University of Kalyani, Vidyasagar University, Sidho-Kanu- Birsa University, Gour Banga University, North Bengal University. The names of the teachers as well as the name of the colleges where the sample teacher respondents are engaged in teaching have been kept confidential for ethical reasons as it was assured to the respondents before filling up of the questionnaire.

\subsection{Data}

The data were collected in July 2014 for the study and is primary in nature. The authors mailed the pre-designed printed questionnaires to eighty respondents chosen randomly from twelve colleges from each of the five universities, namely, Calcutta University, West Bengal State University, University of Burdwan, University of Kalyani, Vidyasagar University and five colleges from Sidho-Kanu- Birsa University, Gour Banga University each and ten colleges from North Bengal University with selfaddressed stamped envelopes and requested the respondents to return back it within a fortnight. The authors received an overwhelming response and got seventy three completely filled up questionnaires before the deadline. Two questionnaires were found partially completed and three reached late by more than a week. The rest two did not reach at all. Considering seven shortfalls in the sample size, the authors sent 
questionnaires to other seven colleges randomly chosen from each one of the universities under study excepting the University of Kalyani. This time all the questionnaires were found to be completed and those reached before the dateline.

\subsection{Tools used}

The questionnaire was structured in such a way that the respondents can answer by choosing any one out of five possibilities - not at all satisfied, not satisfied, somewhat satisfied, satisfied and highly satisfied. This type of responses is called Likert's 5-point scale. Likert type data are used to assessment of attitude of the respondents to one or one set of questions(s) or statement(s). (Likert, 1932). Percentage and frequency have been manually calculated. Arithmetic mean has been calculated by using MS- Excel. Chi-square test has been done manually.

\subsection{Variables used}

The variables chosen for the study include pay, promotion, superannuation, working hours, work load, recognition, teaching aid, infrastructure, co-workers, nonteaching staff, students, Principal etc.

\subsection{Research Findings}

\subsection{Pay and allowances and job satisfaction of the college teachers}

Pay and allowances received by the college teachers is a source of job satisfaction. Though it is claimed that pay and allowances are not actually motivating teachers to perform better and lead to satisfaction, however, a lack of these cause dissatisfaction to the teachers. According to Herzberg's two-factor theory, it has been found that teachers have been giving significantly different reactions over pay and allowances. In the present study, while pay and pay scale made twelve teachers highly satisfied, two teachers were not at all satisfied. With pay and pay scale, 61.25 per cent teachers are either satisfied or highly satisfied whereas only 10 per cent teachers are either not satisfied or highly not satisfied. The expected frequency is significantly different from the observed frequency. The value of chi-square has been found to be 50.125 , far greater than the Table value 9.49 at $5 \%$ level of significance. Similarly, dearness allowances (D.A), a component of pay, also influences the job satisfaction level of college teachers. Regarding D.A., $39(48.75 \%)$ teachers are either not satisfied or highly dissatisfied while only $17(21.25 \%)$ teachers are found to be either satisfied or highly satisfied. H.R.A or house rent allowance is needed by the college teachers like other employees. It also affects the level of job satisfaction of the college teachers. 
54 | MANTHAN: Journal of Commerce and Management, Vol. 2, Issue 2

However, with the present H.R.A., $57.5 \%$ of respondent teachers are satisfied and highly satisfied (46 teachers), while only 20\% (16 teachers) are not satisfied or extremely satisfied teachers. The reactions regarding H.R.A. among the teachers are also varied. The expected frequency is significantly different from observed frequencies causing the value of chi-square at 33.5, which is quite higher than the Table value 7.81 at $5 \%$ level of significance. The medical allowance (M.A.) paid to the teachers is fixed at Rs. 300 per month. This is quite low and very few teachers are extremely satisfied with this provision. Only 14 teachers out of 80 respondents are found to be satisfied with M.A. whereas the number of teachers not at all satisfied and not satisfied is $44(55 \%)$. The value of chi-square is found to be 24.125 which is higher than the table value at $5 \%$ level of significance implying significant differences between observed and expected frequency. Revision of Pay and allowances (ROPA) is generally revised on the basis of recommendations of the Commission constituted for the purpose once in a decade. 47 $(58.75 \%)$ teachers are satisfied either simply and extremely with the existing ROPA system as against only $19(23.75 \%)$ teachers are not satisfied or extremely not satisfied. The value of chi-square statistic is found to be quite high (12.625) indicating significant differences between expected frequency and observed frequencies at 5\% level of significance. Regarding mode of implementation of ROPA system, the college teachers differed in opinion. The not at all satisfied and not satisfied teachers are $31(38.75 \%)$ and satisfied and extremely satisfied teachers are $35(43.75 \%)$. However, the value of chisquare statistic is 2.875 which is less than the table value at $5 \%$ level of significance implying no significant differences between the expected frequency and the observed frequencies. The existing pay-packet system is applicable for all affiliating government aided colleges and it involves quarterly salary payment system instead of monthly system. The teachers expressed high level of dissatisfaction about the pay packet system. $37(46.25 \%)$ teachers are either not satisfied or highly not satisfied whereas $29(36.25 \%)$ teachers are found to be satisfied or highly satisfied. However, the value of chi- square statistic is 3.875 which is also less than the table value 9.49 at $5 \%$ level of significance.

The GPF or general provident fund system is applicable for all whole time teachers of the colleges. The way in which the account of GPF is maintained in the college level is not at all beyond criticism. Due to existence of pay packet system, teachers do not get their salaries in every month as a result they cannot deposit their contributions to the GPF in every month. When the salary is released from the Treasury only then the sum of contribution to the GPF is deducted from their salaries and credited to their GPF accounts. Thus they lose considerable amount of interest for irregular deposits. Again, they do not have separate and personal GPF account of each teacher. They cannot know their current balance of their accounts. The institutional balance can 
be obtained from the DDO. But the segregated amount cannot be known. The interest calculation for the said fund in many colleges is pending for long time. So, at a point of time, a college teacher is unable to know his current balance in the GPF. This lack of transparency causes lack of job satisfaction. 23 teachers expressed their dissatisfaction in contrast to 30 teachers who expressed satisfaction or high degree of satisfaction. The value of chi-square statistic (13.25) is found to be higher than its table value at $5 \%$ level of significance. The TDS (tax deducted at source) system existing in the colleges also a matter of concern in determining job satisfaction level of college teachers. 26 teachers are found to be not satisfied or not all satisfied whereas 29 teachers are satisfied or highly satisfied. The value of chi-square statistic is found to be 10 which is greater than its table value at $5 \%$ level of significance. That is, there exists a significant difference between the observed frequencies and expected frequency. If all the components are taken together the value of chi-square statistic is found to be 53.92 which is quite higher than the table value 9.49 with 4 degrees of freedom at $5 \%$ level of significance. Table 1 depicts the frequency distribution of satisfaction level of college teachers due to pay and allowances along with values of corresponding chi-square statistic. Regarding mode of implementation of ROPA and pay-packet system, chi-square statistics are below the table value and in other components the values of chi-square statistic are greater than the table value.

Table 1: Pay and Allowances and Job Satisfaction levels of College Teachers

\begin{tabular}{|l|c|c|c|c|c|c|c|}
\hline & $\begin{array}{c}\text { Not at all } \\
\text { satisfied } \\
\text { (No. of } \\
\text { teachers) }\end{array}$ & $\begin{array}{c}\text { Not } \\
\text { satisfied } \\
\text { (No. of } \\
\text { teachers) }\end{array}$ & $\begin{array}{c}\text { Somewhat } \\
\text { satisfied } \\
\text { (No. of } \\
\text { teachers) }\end{array}$ & $\begin{array}{c}\text { Satisfied } \\
\text { (No. of } \\
\text { teacher) }\end{array}$ & $\begin{array}{c}\text { Highly } \\
\text { satisfied } \\
\text { (No. of } \\
\text { teachers) }\end{array}$ & Chi-Sq. & Avg \\
\hline $\begin{array}{l}\text { Pay \& Pay } \\
\text { Scale }\end{array}$ & 2 & 6 & 23 & 37 & 12 & $50.125^{*}$ & 3.6375 \\
\hline D.A & 18 & 21 & 24 & 14 & 3 & $16.625^{*}$ & 2.5375 \\
\hline H.R.A & 5 & 11 & 18 & 35 & 11 & $33.5^{*}$ & 3.45 \\
\hline M.A & 15 & 29 & 22 & 10 & 4 & $24.125^{*}$ & 2.4875 \\
\hline ROPA system & 9 & 10 & 14 & 23 & 24 & $12.625^{*}$ & 3.5375 \\
\hline $\begin{array}{l}\text { Mode of } \\
\text { implementation } \\
\text { of ROPA }\end{array}$ & 12 & 19 & 14 & 20 & 15 & 2.875 & 3.0875 \\
\hline $\begin{array}{l}\text { Pay-Packet } \\
\text { system }\end{array}$ & 19 & 18 & 14 & 19 & 10 & 3.875 & 2.7875 \\
\hline GPF system & 7 & 16 & 27 & 17 & 13 & $13.25^{*}$ & 3.1625 \\
\hline TDS system & 9 & 17 & 25 & 18 & 11 & $10^{*}$ & 3.0625 \\
\hline
\end{tabular}

Source: Field Survey. (Total no. of respondents $=80$ ) Chi-square values marked with asterisk are significant at $5 \%$ level of significance. 


\subsection{Promotion and job satisfaction of college teachers}

Promotion rules that exist at present made $35(43.75 \%)$ teachers either extremely satisfied or satisfied and made another 35 teachers either not at all satisfied or not satisfied. It implies that there exist considerable anomalies in the rules making a section satisfied and other part not satisfied. However, the value of chi-square statistic is not significant at 5\% level of significance. Similarly regarding current promotion opportunity existing in the service of college teachers, 34 (42.5\%) teachers are either highly satisfied or satisfied and $27(33.75 \%)$ teachers are not at all satisfied or not satisfied. The value of chi-square has been found to be insignificant at $5 \%$ level of significance. The UGC Regulations, 2010 has introduced performance based appraisal system (PBAS) for the promotion of college teachers. It replaced the UGC Regulations, 2000 where promotion or career advancement of college teachers was based on selfappraisal report (SAR) system. The PBAS has 39 (48.75\%) teachers as satisfied or highly satisfied while $30(37.5 \%)$ teachers are not satisfied. On the other hand, the SAR system has satisfied $36(45 \%)$ teachers while it made $35(43.75 \%)$ teachers dissatisfied. However, the values of chi-square statistics have been found to be insignificant at $5 \%$ level of significance. The components of promotion when taken together give the value of chi-square statistic as 6.7194 which is less than the table value indicating insignificant differences between observed and expected frequencies. Table 2 gives the description of distribution of number of college teachers according to their satisfaction level against the factors relating to promotional aspects of college teachers.

Table 2: Promotion and Job Satisfaction levels of College Teachers

\begin{tabular}{|l|l|l|l|l|l|l|l|}
\hline & $\begin{array}{l}\text { Not at all } \\
\text { satisfied } \\
\text { (No. of } \\
\text { teachers) }\end{array}$ & $\begin{array}{l}\text { Not } \\
\text { satisfied } \\
\text { (Promotion) } \\
\text { (Peachers) }\end{array}$ & $\begin{array}{l}\text { Somewhat } \\
\text { satisfied } \\
\text { (No. of } \\
\text { teachers) }\end{array}$ & $\begin{array}{l}\text { Satisfied } \\
\text { (No. of } \\
\text { teachers) }\end{array}$ & $\begin{array}{l}\text { Highly } \\
\text { satisfied } \\
\text { (No. of } \\
\text { teachers) }\end{array}$ & $\begin{array}{l}\text { Chi- } \\
\text { Sq. }\end{array}$ & Avg. \\
\hline Promotion rules & 17 & 18 & 10 & 21 & 14 & 4.375 & 2.9625 \\
\hline $\begin{array}{l}\text { Promotional } \\
\text { opportunity }\end{array}$ & 11 & 16 & 19 & 19 & 15 & 2.75 & 3.1375 \\
\hline PBAS & 12 & 18 & 11 & 18 & 21 & 4.625 & 3.225 \\
\hline $\begin{array}{l}\text { SAR system of } \\
\text { promotion }\end{array}$ & 20 & 16 & 9 & 19 & 16 & 4.625 & 2.9375 \\
\hline
\end{tabular}

Source: Field Survey. (Total no. of respondents $=80$ ) Chi-square values marked with asterisk are significant at $5 \%$ level of significance. 


\subsection{Superannuation and job satisfaction of college teachers}

Since long the college teachers of West Bengal are expecting that the age of superannuation would increase for a number of years. The UGC Regulations, 2010 clearly spelt out the age of superannuation of college teachers would be 65 years and it would be further extended up to the age of 70 years subject to the availability of vacancy position and health of the teacher going to be retired. But, the state government has not shown interest neither in increasing the age of regular superannuation from 60 to 65 years nor in increasing conditional re-employment up to the age of 70 years. The teachers are also perhaps divided into two in enhancing the age of superannuation. The existing age of superannuation, that is, 60 years has satisfied or extremely satisfied 32 teachers whereas made not satisfied highly and simply 33 teachers. The chi-square statistic calculated has been found to be very small $(0.625)$ in relation to the table value at 5\% level of significance. Pension rules existing at present have made $41(51.25 \%)$ teachers either satisfied or extremely satisfied whereas made not satisfied and not at all satisfied 27 teachers. The chi-square statistic has been found to be insignificant at $5 \%$ level of significance. It is avowedly known that college teachers do not get their superannuation benefits in time. This is a source of serious dissatisfaction. $47(58.75 \%)$ teachers expressed that the mode of payment of superannuation benefits to the college teachers have made them not at all satisfied or not satisfied whereas only 21 teachers are satisfied or highly satisfied with it. The value of chi-square statistic has been found to be 16.438 which is higher than the table value at $5 \%$ level indicating that there exists significant differences among the satisfaction levels of college teachers for the mode of payment of superannuation benefits. The components of superannuation benefits if taken together yields the value of chi-square at 5.396 which is also less than the table value at $5 \%$ level with 4 degrees of freedom. Table-3 gives detailed figures of level of satisfaction of teachers with the values of corresponding chi-square statistic.

\subsection{College specific factors and job satisfaction of college teachers}

Reputation of his college is a source of satisfaction of the concerned teacher. In the present study, $27(33.75 \%)$ teachers expressed that reputation of their college has made them not at all satisfied or not satisfied whereas $42(52.5 \%)$ teachers are satisfied or extremely satisfied with the reputation of their colleges. The value of chi-square statistic has been found to be 6.25 and is less than the table value at $5 \%$ level of significance implying that insignificant differences are there in the level of satisfaction of the college teachers. Location of the college may be either rural or urban. It may be in a district headquarter, capital city, or in a suburb. It may be a near a railway station or a bus stop from where national highway is well connected or in a remote village where 
modern means of transport is insufficient. Teachers have to go to and come from the college every day. Thus distance of his residence is a matter of concern. In the present study, 27 teachers expressed either not satisfaction or extremely satisfaction over the location of the college whereas 43 teachers are satisfied or highly satisfied with the location of the college. If the reporting time is too early or too late or the means of transport communication is unavailable at the time of reporting in the college the teachers coming from a distant place face difficulties. This causes dissatisfaction to them.

Table 3: Superannuation and Job Satisfaction levels of College Teachers

\begin{tabular}{|l|l|l|l|l|l|l|l|}
\hline & $\begin{array}{l}\text { Not at } \\
\text { all } \\
\text { satisfied } \\
\text { (No. of } \\
\text { teachers) }\end{array}$ & $\begin{array}{l}\text { Not } \\
\text { satisfied } \\
\text { (No. of } \\
\text { teachers) }\end{array}$ & $\begin{array}{l}\text { Somewhat } \\
\text { satisfied } \\
\text { (No. of } \\
\text { teachers) }\end{array}$ & $\begin{array}{l}\text { Satisfied } \\
\text { (No. of } \\
\text { teachers) } \\
\text { (Superannuation) }\end{array}$ & $\begin{array}{l}\text { Highly } \\
\text { satisfied(No. } \\
\text { of teachers) }\end{array}$ & (hi-Sq. & Avg. \\
\hline $\begin{array}{l}\text { Age of } \\
\text { superannuation }\end{array}$ & 16 & 17 & 15 & 18 & 14 & 0.625 & 2.962 \\
\hline Pension rules & 12 & 15 & 12 & 23 & 18 & 5.375 & 3.25 \\
\hline $\begin{array}{l}\text { Mode of payment } \\
\text { of superannuation } \\
\text { benefits }\end{array}$ & 29 & 18 & 11 & 12 & 9 & $16.438 *$ & 2.387 \\
\hline
\end{tabular}

Source: Field Survey. (Total no. of respondents $=80$ ) Chi-square values marked with asterisk are significant at $5 \%$ level of significance.

In the present study, 28 teachers are not satisfied or highly dissatisfied with the arrival or reporting time whereas 39 teachers are found to be either satisfied or highly satisfied over the issue of arrival time. The calculated value of chi-square is smaller (2.75) than its tabular value. Working hour is a determinant of level of job satisfaction of college teachers. If a teacher has to spend more time in his college without having meaningful assigned jobs and he is compelled to stay therein, it tells upon the level of his satisfaction. A teacher is generally a liberated soul who used to keep himself busy with constructive socio-cultural-spiritual-academic exercises during his pastime. He might be involved in research work having academic value. Restricting his physical presence forcefully after his assigned job may hurt his creativity. However, in the present study, 26 teachers are found to be not satisfied or not at all satisfied whereas, 39 teachers are found to be satisfied or extremely satisfied. The chi-square value is only 3.125 and is insignificant being less than the table value. 
The existing provisions of holidays in the academic calendar and provisions of leaves in the statute of the universities have satisfied simply or highly $49(61.25 \%)$ teachers whereas 15 teachers are found to be not satisfied simply or highly with holidays and leaves. The value of chi-square calculated is 18.875 which is greater the table value of at 5\% level of significance implying that there exists significant differences in the level of satisfaction of the teachers regarding holidays and leaves. Work load is also an important determinant of job satisfaction. Few teachers are over-burdened with their work load. They have many students and classes; many answer scripts, many extracurricular activities and many administrative responsibilities. Some teachers are exempted from many responsibilities. This inequity and the stress originating from over burden causes dissatisfaction. 22 teachers, in this study, have shown their simple and extreme dissatisfaction about work load assigned to them whereas 41 teachers (almost double in number) have shown satisfaction and extreme satisfaction about their work loads. (Table 4)

Table 4: College-specific Criteria and Job Satisfaction levels of College Teachers

\begin{tabular}{|c|c|c|c|c|c|c|c|}
\hline $\begin{array}{l}\text { Factors } \\
\text { (College-specific) }\end{array}$ & $\begin{array}{l}\text { Not at } \\
\text { all } \\
\text { satisfied } \\
\text { (No. of } \\
\text { teachers) }\end{array}$ & $\begin{array}{l}\text { Not } \\
\text { satisfied } \\
\text { (No. of } \\
\text { teachers) }\end{array}$ & $\begin{array}{l}\text { Somewhat } \\
\text { satisfied } \\
\text { (No. of } \\
\text { teachers) }\end{array}$ & $\begin{array}{l}\text { Satisfied } \\
\text { (No. of } \\
\text { teachers) }\end{array}$ & $\begin{array}{l}\text { Highly } \\
\text { satisfied } \\
\text { (No. of } \\
\text { teachers) }\end{array}$ & $\begin{array}{l}\text { Chi- } \\
\text { Sq. }\end{array}$ & Avg. \\
\hline $\begin{array}{l}\text { Reputation of the } \\
\text { college }\end{array}$ & 12 & 15 & 11 & 19 & 23 & 6.25 & 3.325 \\
\hline $\begin{array}{l}\text { Location of the } \\
\text { college }\end{array}$ & 11 & 16 & 10 & 21 & 22 & 7.625 & 3.337 \\
\hline $\begin{array}{l}\text { Reporting time of } \\
\text { arrival }\end{array}$ & 13 & 15 & 13 & 20 & 19 & 2.75 & 3.212 \\
\hline Working hour & 12 & 14 & 15 & 18 & 21 & 3.125 & 3.275 \\
\hline $\begin{array}{l}\text { No. of holidays } \\
\text { and leaves }\end{array}$ & 5 & 10 & 16 & 25 & 24 & $18.875^{*}$ & 3.662 \\
\hline $\begin{array}{l}\text { Work load } \\
\text { assigned }\end{array}$ & 10 & 12 & 17 & 24 & 17 & 7.375 & 3.325 \\
\hline Freedom at classes & 11 & 13 & 15 & 21 & 20 & 4.75 & 3.325 \\
\hline $\begin{array}{l}\text { Medium of } \\
\text { instruction }\end{array}$ & 7 & 8 & 14 & 26 & 25 & $20.625 *$ & 3.675 \\
\hline
\end{tabular}

Source: Field Survey. (Total no. of respondents $=80$ ) Chi-square values marked with asterisk are significant at $5 \%$ level of significance. 
Freedom at classes is very important for a teacher and he generally expects to be the supreme authority in the class. If he is given too many suggestions from outsiders, may be from the principal, senior colleagues, students' leaders or some other corners, he feels humiliated. In the present study, 24 teachers are found to be not satisfied or extremely dissatisfied whereas 41 teachers are found to be highly satisfied or satisfied about freedom at classes. The calculated value of chi-square is found to be 4.75 which is less than table value. Teachers with origin from Bihar, Uttar Pradesh, Orissa, Rajasthan, Sikkim, Assam and even from Darjeeling find difficulty in teaching Bengali. Again, the Bengali teachers are not always found to be very fluent in English or Hindi. Thus, if the medium of instruction of the college does not fit with the teacher concerned then the satisfaction level is affected seriously. In the present study, only 15 teachers are found to be not satisfied and not satisfied at all while 51 teachers are found to be satisfied or highly satisfied. The chi-square calculated is 20.625 , higher than the table value of it at $5 \%$ level of significance. There exists a significant difference between observed frequencies and expected frequencies. Table 4 depicts the all the above relevant information in details.

\subsection{Students related factors and job satisfaction of college teachers}

The teacher-pupil ratio is miserably poor in the colleges of West Bengal. Most of the departments are running with a single full time teacher with the aids of part time and contractual teachers. In the present study, 33 teachers are not satisfied or not at all satisfied with the teacher-pupil ratio in their colleges. On the other hand, only 23 teachers are satisfied or highly satisfied with the teacher-pupil ratio. The quality of students is an important determinant of job satisfaction of the college teachers. A teacher's performance is judged by the students' academic progress. If he is given low quality students and students who do not have any intention of learning and if they are very much irregular in attendance then despite the teacher's high teaching capability no reflection is noticed in the report cards of the students. In this study, 35 teachers are found to be dissatisfied whereas 22 teachers are found to be satisfied or highly satisfied. At the college level, some students are found to be disobedient who disturb not only their classmates but also the teachers. A sense of heroism works in their minds and this type of students is to be dealt with care. A proper counseling is needed for them. They are to be treated in such a way that this phenomenon does not spread over to other students. 22 teachers are found to be not satisfied about the treatment of disobedient students while 27 teachers are satisfied or highly satisfied. The value of chi-square is 18.875 which is greater than the table value. There exist significant differences between expected frequency and observed frequencies. Punctuality and regularity are the signs of 
discipline in a college. A teacher is satisfied if discipline is maintained in true sense. 20 teachers are not satisfied or highly dissatisfied with discipline whereas 37 teachers are satisfied or highly satisfied with the discipline maintained in their colleges. Table 5 gives the details of student related factors and their influence on job satisfaction.

Table 5: Students related factors and Job Satisfaction levels of College Teachers

\begin{tabular}{|l|c|l|l|l|l|l|l|}
\hline $\begin{array}{l}\text { Factors } \\
\text { (Students } \\
\text { related) }\end{array}$ & $\begin{array}{l}\text { Not at all } \\
\text { satisfied } \\
\text { (No. of } \\
\text { teachers) }\end{array}$ & $\begin{array}{l}\text { Not } \\
\text { satisfied } \\
\text { (No. of } \\
\text { teachers) }\end{array}$ & $\begin{array}{l}\text { Somewhat } \\
\text { satisfied } \\
\text { (No. of } \\
\text { teachers) }\end{array}$ & $\begin{array}{l}\text { Satisfied } \\
\text { (No. of } \\
\text { teachers) }\end{array}$ & $\begin{array}{l}\text { Highly } \\
\text { satisfied(No. } \\
\text { of teachers) }\end{array}$ & $\begin{array}{l}\text { Chi- } \\
\text { Sq. }\end{array}$ & Avg. \\
\hline $\begin{array}{l}\text { Pupil-teacher } \\
\text { ratio }\end{array}$ & 15 & 18 & 24 & 14 & 9 & 7.625 & 2.8 \\
\hline $\begin{array}{l}\text { Quality of } \\
\text { students }\end{array}$ & 16 & 19 & 23 & 15 & 7 & 8.75 & 2.725 \\
\hline $\begin{array}{l}\text { Action against } \\
\text { disobedient } \\
\text { student }\end{array}$ & 10 & 12 & 31 & 16 & 11 & $18.875^{*}$ & 3.075 \\
\hline Discipline & 8 & 12 & 23 & 20 & 17 & 9.125 & 3.325 \\
\hline
\end{tabular}

Source: Field Survey. (Total no. of respondents $=80$ ) Chi-square values marked with asterisk are significant at $5 \%$ level of significance.

\subsection{Examination, admission, election and job satisfaction of college teachers}

Examination, admission and election of the students' union are regular and mandatory events that take place in each year and in every college. Teachers want peaceful completion of these events and an ambience for providing quality education to be maintained. Departure from this affects the satisfaction level of job satisfaction. In the present study, 35, 32 and 38 teachers are found to be not satisfied and not at all satisfied in the context of the way examination, admission and election are held respectively. As against this, 30, 38 and 26 teachers are found to be satisfied or extremely satisfied with the way examination, admission and election are held respectively. The values of chisquare calculated are found to be smaller than the table value of it. Table 6 presents the detailed information about these aspects of job satisfaction.

\subsection{Academic facilities and job satisfaction of college teachers}

Library facility, access to internet connectivity, laboratory facility, computer facility, safe drinking water facility, availability of teaching aids, adequate number of 
class rooms, facility of audio-visual class rooms, airy and spacious staff room, clean and dry toilets facility and research facility etc. constitute the infrastructure of a college.

Table 6: Major Events and Job Satisfaction levels of College Teachers

\begin{tabular}{|l|l|l|l|l|l|l|l|}
\hline $\begin{array}{l}\text { Factors } \\
\text { (Examination- } \\
\begin{array}{l}\text { Admission- } \\
\text { Election) }\end{array}\end{array}$ & $\begin{array}{l}\text { Not at all } \\
\text { satisfied } \\
\text { (No. of } \\
\text { teachers) }\end{array}$ & $\begin{array}{l}\text { Not } \\
\text { satisfied } \\
\text { (No. of } \\
\text { teachers) }\end{array}$ & $\begin{array}{l}\text { Somewhat } \\
\text { satisfied } \\
\text { (No. of } \\
\text { teachers) }\end{array}$ & $\begin{array}{l}\text { Satisfied } \\
\text { (No. of } \\
\text { teachers) }\end{array}$ & $\begin{array}{l}\text { Highly } \\
\text { satisfied(No. } \\
\text { of teachers) }\end{array}$ & $\begin{array}{l}\text { Chi- } \\
\text { Sq. }\end{array}$ & Avg. \\
\hline Examination & 16 & 19 & 15 & 22 & 8 & 6.875 & 2.8375 \\
\hline Admission & 15 & 17 & 10 & 19 & 19 & 3.5 & 3.15 \\
\hline $\begin{array}{l}\text { Election of } \\
\text { Students, } \\
\text { union }\end{array}$ & 17 & 21 & 16 & 16 & 10 & 3.875 & 2.7625 \\
\hline
\end{tabular}

Source: Field Survey. (Total no. of respondents $=80)$ Chi-square values marked with asterisk are significant at $5 \%$ level of significance.

If infrastructure is found to be adequate, job satisfaction of college teachers is positively affected. In this study, teachers who are not satisfied and not at all satisfied exceeds in number than satisfied and highly satisfied teachers in access to internet connectivity and laboratory facility. In all other cases, satisfied and highly satisfied teachers are greater in number. The value of chi-square statistic has been found to be greater than its tabular values in case of research facility (Table 7)

\subsection{Supervision and Job Satisfaction of College Teachers}

Managerial ability of the Principal is a very important determinant of job satisfaction of college teachers. He visualizes the future of the college and gets jobs done in time by his staff. In this study, 30 teachers are either not satisfied or not at all satisfied while 28 teachers are satisfied or highly satisfied with the managerial ability of the Principal. A teacher's job satisfaction is supposed to increase, if the principal seeks the teacher's opinion about any academic reform and the opinion suggested is given due importance. In the present study, 27 teachers are not satisfied or not at all satisfied with the importance given by the Principal to a teacher's opinion in academic interest while for the same 33 teachers are satisfied or extremely satisfied. The warm relation with the Principal is also an important factor determining satisfaction. 31 teachers are not satisfied or not at all satisfied with the relationship with the principal while 29 teachers are satisfied or highly satisfied. The style of functioning of the principal is a major 
concern of the college teachers as it directly relates with the job satisfaction of the teachers. He may be autocratic, vindictive, participatory or democratic. Quite naturally, the last two types of functioning yield higher satisfaction to the teachers. 27 teachers are not satisfied or not at all satisfied whereas 32 teachers are satisfied or highly satisfied the way of functioning of the principal.

Table 7: Infrastructure Facilities and Job Satisfaction levels of College Teachers

\begin{tabular}{|l|l|l|c|l|l|l|l|}
\hline $\begin{array}{l}\text { Factors } \\
\text { (Facilities) }\end{array}$ & $\begin{array}{l}\text { Not at all } \\
\text { satisfied } \\
\text { (No. of } \\
\text { teachers) }\end{array}$ & $\begin{array}{l}\text { Not } \\
\text { satisfied } \\
\text { (No. of } \\
\text { teachers) }\end{array}$ & $\begin{array}{l}\text { Somewhat } \\
\text { satisfied } \\
\text { (No. of } \\
\text { teachers) }\end{array}$ & $\begin{array}{l}\text { Satisfied } \\
\text { (No. of } \\
\text { teachers) }\end{array}$ & $\begin{array}{l}\text { Highly } \\
\text { satisfied(No. } \\
\text { of teachers) }\end{array}$ & $\begin{array}{l}\text { Chi- } \\
\text { Sq. }\end{array}$ & Avg. \\
\hline Library & 10 & 13 & 15 & 22 & 20 & 6.125 & 3.3625 \\
\hline $\begin{array}{l}\text { Access to } \\
\text { internet } \\
\text { connectivity }\end{array}$ & 19 & 18 & 12 & 17 & 14 & 2.125 & 2.8625 \\
\hline Laboratory & 21 & 22 & 14 & 13 & 10 & 6.875 & 2.6125 \\
\hline Computer & 15 & 17 & 16 & 18 & 14 & 0.625 & 2.9875 \\
\hline Drinking water & 9 & 14 & 15 & 24 & 18 & 7.625 & 3.35 \\
\hline Teaching aid & 12 & 15 & 19 & 18 & 16 & 1.875 & 3.1375 \\
\hline $\begin{array}{l}\text { Audio-visual } \\
\text { (smart classes) } \\
\text { classrooms }\end{array}$ & 10 & 13 & 26 & 17 & 14 & 9.375 & 3.15 \\
\hline Staff room & 15 & 16 & 17 & 17 & 15 & 0.25 & 3.0125 \\
\hline Toilet & 10 & 16 & 18 & 19 & 17 & 3.125 & 3.2125 \\
\hline $\begin{array}{l}\text { Research } \\
\text { facility }\end{array}$ & 8 & 13 & 29 & 19 & 11 & $17.25 *$ & 3.15 \\
\hline
\end{tabular}

Source: Field Survey. (Total no. of respondents $=80$ ) Chi-square values marked with asterisk are significant at $5 \%$ level of significance.

After having done a better performance, a teacher deserves proper recognition from the college authority and if it remains unnoticed and neglected intentionally the satisfaction level is influenced. 21 teachers are not satisfied or not at all satisfied while 43 teachers are satisfied or highly satisfied. Teachers always prefer to utilize the scope of learning. Attending seminars and conferences give them fresh air and inspires them to think of new and better ideas. Such opportunities for attending seminars and conferences are given by the Principal. 28 teachers were found to be not satisfied or not at all satisfied with the opportunity given for attending seminars and conferences while 39 teachers are satisfied or highly satisfied with the opportunity (Table 8). 
64 | MANTHAN: Journal of Commerce and Management, Vol. 2, Issue 2

Table 8: Supervision and Job Satisfaction levels of College Teachers

\begin{tabular}{|l|l|l|l|l|l|l|l|}
\hline $\begin{array}{l}\text { Factors } \\
\text { (Supervision) }\end{array}$ & $\begin{array}{l}\text { Not at } \\
\text { all } \\
\text { satisfied } \\
\text { (No. of } \\
\text { teachers) }\end{array}$ & $\begin{array}{l}\text { Not } \\
\text { satisfied } \\
\text { (No. of } \\
\text { teachers) }\end{array}$ & $\begin{array}{l}\text { Somewhat } \\
\text { satisfied } \\
\text { (No. of } \\
\text { teachers) }\end{array}$ & $\begin{array}{l}\text { Satisfied } \\
\text { (No. of } \\
\text { teachers) }\end{array}$ & $\begin{array}{l}\text { Highly } \\
\text { satisfied } \\
\text { (No. of } \\
\text { teachers) }\end{array}$ & Chi-Sq. & Avg. \\
\hline $\begin{array}{l}\text { Managerial } \\
\text { ability } \\
\text { of the Principal }\end{array}$ & 13 & 17 & 22 & 16 & 12 & 3.875 & 2.9625 \\
\hline $\begin{array}{l}\text { Importance of } \\
\text { teachers' } \\
\text { opinion }\end{array}$ & 14 & 13 & 20 & 19 & 14 & 2.625 & 3.075 \\
\hline $\begin{array}{l}\text { Relationship } \\
\text { with } \\
\text { the Principal }\end{array}$ & 14 & 17 & 20 & 14 & 15 & 1.625 & 2.9875 \\
\hline $\begin{array}{l}\text { Style of } \\
\text { functioning } \\
\text { of the Principal }\end{array}$ & 12 & 15 & 21 & 16 & 16 & 2.625 & 3.1125 \\
\hline $\begin{array}{l}\text { Recognition } \\
\text { of teachers } \\
\text { for better } \\
\text { performance }\end{array}$ & 9 & 12 & 16 & 19 & 24 & 8.625 & 3.4625 \\
\hline $\begin{array}{l}\text { Opportunity } \\
\text { for attending } \\
\text { seminars } \\
\& \text { conferences }\end{array}$ & 13 & 15 & 13 & 23 & & & \\
\hline
\end{tabular}

Source: Field Survey. (Total no. of respondents $=80$ )

\subsection{Co-workers and stakeholders and job satisfaction of college teachers}

Teachers live in the world of colleagues. The image of a teacher produced by his colleagues is an important part of the identity of the concerned teacher. If they think that the teacher is efficient, responsible, punctual and student-friendly, then he becomes so in the eyes of the others. The relationship with the colleagues is very important determinant of job satisfaction. 27 teachers, in this study, are not satisfied or not at all satisfied with their colleagues whereas 35 teachers are satisfied and highly satisfied. 39 teachers are not satisfied or not at all satisfied with the non-teaching staff whereas 26 are satisfied or highly satisfied. 26 teachers are not satisfied with the relationship with the students' union activists while 40 are satisfied and highly satisfied. 20 teachers are not satisfied or not at all satisfied with the relationship with general students whereas 47 teachers are satisfied or satisfied with them. 36 teachers are not satisfied or not at all satisfied with 
the guardians and parents of the students who have sent their wards to the college teachers for learning and 22 teachers are satisfied or highly satisfied with them. The values of chi-square calculated have been found to be its tabular value in case of relationship with general students (Table 9).

Table-9: Co-workers and Stakeholders and Job Satisfaction levels of College Teachers

\begin{tabular}{|c|c|c|c|c|c|c|c|}
\hline $\begin{array}{l}\text { Factors (Co- } \\
\text { workers } \\
\text { \& Stakeholders) }\end{array}$ & $\begin{array}{l}\text { Not at all } \\
\text { satisfied } \\
\text { (No. of } \\
\text { teachers) }\end{array}$ & $\begin{array}{l}\text { Not } \\
\text { satisfied } \\
\text { (No. of } \\
\text { teachers) }\end{array}$ & $\begin{array}{l}\text { Somewhat } \\
\text { satisfied } \\
\text { (No. of } \\
\text { teachers) }\end{array}$ & $\begin{array}{l}\text { Satisfied } \\
\text { (No. of } \\
\text { teachers) }\end{array}$ & $\begin{array}{l}\text { Highly } \\
\text { satisfied(No. } \\
\text { of teachers) }\end{array}$ & $\begin{array}{l}\text { Chi- } \\
\text { Sq. }\end{array}$ & Avg. \\
\hline $\begin{array}{l}\text { Relationship with } \\
\text { Colleagues }\end{array}$ & 11 & 16 & 18 & 19 & 16 & 2.375 & 3.1625 \\
\hline $\begin{array}{l}\text { Relationship with } \\
\text { non-teaching staff }\end{array}$ & 19 & 20 & 15 & 17 & 9 & 4.75 & 2.7125 \\
\hline $\begin{array}{l}\text { Relationship with } \\
\text { students' union } \\
\text { activists }\end{array}$ & 12 & 14 & 14 & 23 & 17 & 4.625 & 3.2375 \\
\hline $\begin{array}{l}\text { Relationship with } \\
\text { students as a whole }\end{array}$ & 9 & 11 & 13 & 31 & 16 & $19.25^{*}$ & 3.425 \\
\hline $\begin{array}{l}\text { Relationship with } \\
\text { parents and } \\
\text { guardians }\end{array}$ & 17 & 19 & 22 & 16 & 6 & 9.125 & 2.6875 \\
\hline
\end{tabular}

Source: Field Survey. (Total no. of respondents $=80$ ) Chi-square value marked with asterisk is significant at $5 \%$ level of significance.

\subsection{Work Environment and Community Support and Job Satisfaction of College Teachers}

Work environment is an important determinant of job satisfaction of college teachers. The findings of the study on this aspect revealed that 26 teachers were either not satisfied or not at all satisfied with the work environment prevailing in the college whereas 36 teachers are either satisfied or highly satisfied with the work environment. Community support is very necessary for proper functioning of the college. 18 teachers are either not satisfied or not at all satisfied with the extent of community support whereas 33 teachers are either satisfied or highly satisfied. The value of chi-square 
statistic is calculated to be 17.125 and is higher than its tabular value indicating there are significant differences between the observed frequencies and expected frequency. Table10 gives detail information about the satisfaction level of job satisfaction of college teachers regarding work environment and community support.

Table 10: Work Environment and Community Support and Job Satisfaction levels of College Teachers

\begin{tabular}{|l|c|c|c|c|c|c|c|}
\hline $\begin{array}{l}\text { Factors } \\
\text { (Work } \\
\text { environment } \\
\text { and } \\
\text { Community } \\
\text { support) }\end{array}$ & $\begin{array}{l}\text { Not at all } \\
\text { satisfied } \\
\text { (No. of } \\
\text { teachers) }\end{array}$ & $\begin{array}{l}\text { Not } \\
\text { satisfied } \\
\text { (No. of } \\
\text { teachers) }\end{array}$ & $\begin{array}{l}\text { Somewhat } \\
\text { satisfied } \\
\text { (No. of } \\
\text { teachers) }\end{array}$ & $\begin{array}{l}\text { Satisfied } \\
\text { (No. of } \\
\text { teachers) }\end{array}$ & $\begin{array}{l}\text { Highly } \\
\text { satisfied } \\
\text { (No. of } \\
\text { teachers) }\end{array}$ & $\begin{array}{l}\text { Chi- } \\
\text { Sq. }\end{array}$ & Avg. \\
\hline $\begin{array}{l}\text { Work } \\
\text { environment } \\
\text { of the } \\
\text { college }\end{array}$ & 12 & 14 & 18 & 19 & 17 & 2.125 & 3.1875 \\
\hline $\begin{array}{l}\text { Community } \\
\text { support } \\
\text { for the } \\
\text { college }\end{array}$ & 8 & 10 & 29 & 18 & 15 & $17.125 *$ & 3.275 \\
\hline
\end{tabular}

Source: Field Survey. (Total no. of respondents = 80) Chi-square value marked with asterisk is significant at $5 \%$ level of significance.

Table 11 shows the frequency distribution of college teachers according to their overall job satisfaction. The average is in favour of satisfied college teachers. That is, most of the teachers are satisfied with their jobs, in general.

Table 11: Overall Job Satisfaction Levels of College Teachers

\begin{tabular}{|c|c|c|c|c|c|c|c|}
\hline $\begin{array}{l}\text { Factors } \\
\text { (Overall } \\
\text { satisfaction) } \\
\end{array}$ & $\begin{array}{l}\text { Not at all } \\
\text { satisfied } \\
\text { (No. of } \\
\text { teachers) } \\
\end{array}$ & $\begin{array}{l}\text { Not } \\
\text { satisfied } \\
\text { (No. of } \\
\text { teachers) } \\
\end{array}$ & $\begin{array}{l}\text { Somewhat } \\
\text { satisfied } \\
\text { (No. of } \\
\text { teachers) } \\
\end{array}$ & $\begin{array}{l}\text { Satisfied } \\
\text { (No. of } \\
\text { teachers) }\end{array}$ & $\begin{array}{l}\text { Highly } \\
\text { satisfied } \\
\text { (No. of } \\
\text { teachers) } \\
\end{array}$ & Chi-Sq. & Avg. \\
\hline $\begin{array}{l}\text { Overall } \\
\text { satisfaction }\end{array}$ & 7 & 11 & 18 & 25 & 19 & $12.5^{*}$ & 3.475 \\
\hline
\end{tabular}

\subsection{Conclusion}

Job satisfaction of college teachers is an important issue for taking up research so that adequate and relevant policy prescriptions can be brought into the notice of the 
policy makers of the country. It depends upon broadly three types of factors - personal characteristics of the teachers, institutional characteristics and provisions and environmental or system characteristics. The present paper found that pay and allowances, promotion, superannuation, college specific criteria, students related matter, examination-admission-election processes, infrastructure facilities, supervision, coworkers and stakeholders and work environment and community support have influences on job satisfaction of college teachers. Within limited scope, averages job satisfaction of college teachers have been estimated for each factor by using Likert's 5-point scale. The value of average when exceeds 3 (median value as well as arithmetic mean) can be treated as satisfied. Thus 29 out of 55 factors are found to be affecting job satisfaction positively. Thus, in general, the study concludes that college teachers of degree colleges are satisfied in West Bengal.

\section{References}

Feldman, D., \& Arnold, H. (1983). Managing Individual and Group Behaviour in Organizations. New York: Mc Graw Hill.

Hulin, C., \& Judge, T. (2003). Job Attitudes . In W. Borman, D. Ilgen, \& Klimoski, Handbook of Psychology (pp. 255-276). New Jersey: Wiley.

K, D., \& Newstorm, J. (1989). Human Behaviou at Work. New York: Mc Graw Hill.

Likert, R. (1932). A Technique for the Measurement of Attitudes. New York: Archives of Psychology.

Roy, S. (2015). Assessment of Job Satisfaction of College Teachers: Focus on Methodology. INSPIRA-Journal of Modern Management \& Entrepreneurship 5(3), 7384.

Roy, S., \& Roy, S. (2013). Job Satisfaction of College Teachers - An Elementary Study in West Bengal. Business Perspective, Vol. 4 , 62-77.

Shann, M. (1998). Professional Commitment and Satisfaction among Teachers in Urban Middle Schools. Journal of Educational Research 92(2), 67-74.

Spector, P. (1997). Job Satisfaction: Application, Assessment, Causes and Consequences. California: Sage Publications. 